\title{
ANALISIS PENINGKATAN KEMAMPUAN PENALARAN MATEMATIS MELALUI PENERAPAN MODEL PEMBELAJARAN PROBLEM POSING DITINJAU BERDASARKAN KEMAMPUAN AWAL MATEMATIS SISWA
}

\section{ANALYSIS OF IMPROVING MATHEMATICAL REASONING BY IMPLEMENTATION OF PROBLEM POSING LEARNING MODEL BASED ON STUDENTS' EARLY MATHEMATICAL ABILITY}

\author{
Abdul Rosyid, Zuli Nuraeni, Atik Apriati \\ STKIP Muhammadiyah Kuningan, Jln. Murtasiah Supomo No.28B Kuningan, \\ adromath_dosen@upmk.ac.id, zulinura@upmk.ac.id, tike.zaprill@gmail.com
}

\begin{abstract}
ABSTRAK
Tulisan ini bertujuan untuk menelaah peningkatan kemampuan penalaran matematis siswa melalui model pembelajaran problem posing ditinjau berdasarkan kemampuan awal matematis (KAM) siswa. Data KAM pada tulisan ini adalah nilai ulangan harian siswa pada pokok bahasan sebelumnya yang kemudian dikelompokkan menjadi kategori Tinggi, Sedang, dan Rendah. Metode penelitian yang digunakan adalah metode penelitian eksperimen dengan desain nonequivalent control group design. Teknik analisis data yang digunakan meliputi Uji Normalitas, Uji Homogenitas, Uji t, Uji t', Uji Mann Whitney, serta Uji Anova Satu Jalur dan Uji Kruskal Wallis. Data hasil penelitian menunjukkan rata-rata $\mathrm{N}$-Gain kelas eksperimen 0,48 sedangkan rata-rata $\mathrm{N}$ Gain kelas kontrol 0,18. Selanjutnya rata-rata N-Gain kelas eksperimen kelompok KAM tinggi 0,56; kelompok KAM sedang 0,45; kelompok KAM rendah 0,49. Sedangkan rata-rata N-Gain kelas kontrol kelompok KAM tinggi 0,11; kelompok KAM sedang 0,21; kelompok KAM rendah 0,13 . Berdasarkan analisis yang dilakukan, diperoleh kesimpulan bahwa apabila ditinjau secara keseluruhan, peningkatan kemampuan penalaran matematis siswa yang memperoleh pembelajaran matematika melalui model pembelajaran problem posing lebih baik daripada peningkatan kemampuan penalaran matematis siswa yang memperoleh pembelajaran matematika secara konvensional. Selanjutnya apabila ditinjau berdasarkan kategori KAM tinggi, sedang, dan rendah, tidak terdapat perbedaan peningkatan kemampuan penalaran matematis baik itu pada siswa yang memperoleh pembelajaran matematika melalui model pembelajaran problem posing maupun pada siswa yang memperoleh pembelajaran matematika secara konvensional. Akan tetapi pada kategori KAM tinggi, sedang, dan rendah, peningkatan kemampuan penalaran matematis siswa yang memperoleh pembelajaran matematika melalui model pembelajaran problem posing lebih baik daripada peningkatan kemampuan pemecahan masalah matematis siswa yang memperoleh pembelajaran matematika secara konvensional.
\end{abstract}

Kata kunci: Problem Posing, Penalaran Matematis, Kemampuan Awal Matematis

\section{ABSTRACT}

This paper is intended to examine the improvement of students' mathematical reasoning by the problem posing model based on students' early mathematical ability (KAM). KAM data in this paper is the score of student's daily test on the previous subject which then grouped into categories High, Medium, and Low. This research used experimental research method with nonequivalent control group design. Data analysis technique used Normality Test, Homogeneity Test, $t$ test, $t$ ' 
test, Mann Whitney Test, One-way ANOVA Test, and Kruskal Wallis Test. The result shows that mean of $N$-Gain experiment class is 0,48 whereas mean of $N$-Gain control class is 0,18. Furthermore, the average $N$-Gain experimental class of high KAM group is 0.56; Medium KAM group is 0.45; Low KAM group is 0.49. While the average N-Gain control class of high KAM group is 0.11; Medium KAM group is 0.21; Low KAM group is 0.13. Based on the analysis, it can be concluded that if reviewed in whole, the improvement of students 'mathematical reasoning by problem posing model is better than the improvement of students 'mathematical reasoning by conventional mathematics learning. Furthermore, when reviewed based on high, medium, and low KAM categories, there is no difference in the improvement of mathematical reasoning either in students who obtained learning mathematics through the problem posing model and in students who received conventional mathematics learning. However, in the high, medium, and low category of KAM, the improvement of students' mathematical reasoning by the problem posing model is better than the improvement of students' mathematical reasoning by conventional mathematics learning.

Keywords: Problem Posing, Mathematical Reasoning, Early Mathematical Ability

\section{How to Cite: Rosyid, A., Nuraeni, Z., \& Apriati, A. (2018). Analisis Peningkatan Kemampuan Penalaran Matematis Melalui Penerapan Model Pembelajaran Problem Posing Ditinjau Berdasarkan Kemampuan Awal Matematis Siswa. Mathline: Jurnal Matematika dan Pendidikan Matematika, Vol.3, No.1, 11-22.}

\section{PENDAHULUAN}

Matematika merupakan salah satu mata pelajaran yang dianggap sangat sulit oleh sebagian besar siswa, sehingga minat siswa untuk mempelajarinya rendah. Oleh karena itu pembelajaran matematika harus benar-benar berjalan dengan baik sesuai dengan tujuan pembelajaran matemaika. Adapun tujuan pembelajaran matematika di sekolah menurut National Council of Teachers of Mathematics (NCTM) adalah mengembangkan kemampuan: komunikasi matematis, penalaran matematis, pemecahan masalah matematis, koneksi matematis (Shadiq, 2014). Salah satu tujuan pembelajaran matematika yaitu untuk mengembangkan kemampuan penalaran matematika siswa. Berarti kemampuan penalaran mempunyai fungsi yang sangat penting serta sangat berpengaruh dalam menyelesaikan suatu permasalahan dalam pembelajaran matematika.

Secara garis besar kemampuan penalaran matematika terdiri dari dua jenis yaitu penalaran induktif dan penalaran deduktif. Untuk tingkat matematika SMP, penalaran induktif meliputi membuat perkiraan, menarik analogi, dan menarik generalisasi, serta penalaran deduktif meliputi membuktikan secara langsung (Sumarmo, 2013). Sedangkan pada tingkatan SMP, kemampuan penalaran matematika yang ditekankan adalah kemampuan penalaran induktif karena kemampuan penalaran induktif memiliki tingkatan rendah. 
Berdasarkan hasil wawancara dengan guru mata pelajaran Matematika di MTs Ar Raswad Cengal menyatakan bahwa kemampuan penalaran matematika siswa masih sangat rendah. Terlihat dari hasil observasi awal nilai rata-rata kemampuan penalaran matematika siswa adalah 37,5 dari 36 siswa, serta persentase siswa yang lulus dari nilai KKM 70 hanya 11,11\%. Dengan ditemukannya permasalahan tersebut, guru hendaknya mampu memilih model pembelajaran yang lebih menarik dan memicu keaktifan siswa, serta guru harus bisa memposisikan diri dan menentukan model pembelajaran yang sesuai dengan materi yang hendak disampaikan.

Model pembelajaran problem posing memungkinkan siswa aktif dalam pembelajaran karena model pembelajaran ini lebih menekankan pada siswa yang berperan aktif untuk mengajukan permasalahan. Problem posing merupakan model pembelajaran yang mengharuskan siswa menyusun pertanyaan sendiri atau memecahkan masalah suatu soal menjadi pertanyaan-pertanyaan yang lebih sederhana (Shohimin, 2014).

Menurut Silver (1994) problem posing mempunyai tiga pengertian, yaitu: 1) problem posing adalah perumusan soal sederhana atau perumusan ulang soal yang ada dengan beberapa perubahan agar lebih sederhana dan dapat dipahami dalam memecahkan soal yang rumit; 2) problem posing adalah perumusan soal yang berkaitan dengan syaratsyarat pada soal yang telah diselesaikan untuk mencari alternatif pemecahan lain atau mengkaji kembali langkah penyelesaian masalah yang telah dilakukan; 3) problem posing adalah merumuskan atau membuat soal dari situasi yang diberikan (Lestari \& Yudhanegara, 2015). Model pembelajaran problem posing memiliki kelebihan, diantaranya mendidik murid untuk berpikir kritis, siswa aktif dalam pembelajaran, perbedaan pendapat antara siswa dapat diketahui dengan mudah diarahkan pada diskusi yang sehat, belajar menganalisis suatu masalah, dan mendidik anak percaya pada diri sendiri (Shohimin, 2014).

Mengingat matematika adalah ilmu yang terstruktur, artinya untuk memahami suatu konsep matematika diperlukan penguasaan konsep dasar matematika lainnya, maka kemampuan kognitif awal siswa memegang peranan penting dalam penguasaan konsep baru matematika. Oleh karena itu, paparan dalam tulisan ini akan menelaah peningkatan kemampuan penalaran matematis siswa melalui model pembelajaran problem posing ditinjau berdasarkan kemampuan awal matematis (KAM) siswa. Data KAM diperoleh melalui tes yang telah diberikan sebelum penelitian dilakukan. Dengan kata lain, untuk memperoleh data KAM, peneliti tidak perlu memberikan tes terlebih dahulu kepada siswa 
(Lestari \& Yudhanegara, 2015). Data KAM pada tulisan ini adalah nilai ulangan harian siswa pada pokok bahasan sebelumnya.

\section{METODE PENELITIAN}

Metode penelitian yang digunakan adalah metode penelitian eksperimen. Metode penelitian eksperimen merupakan metode penelitian yang digunakan untuk mencari pengaruh perlakuan tertentu terhadap yang lain dalam kondisi yang terkendalikan (Sugiyono, 2013). Adapun desain penelitiannya yaitu nonequivalent control group design yang hampir sama dengan pretest-postest control group design, namun pada design ini sampel tidak dipilih secara random, design ini merupakan salah satu jenis desain quasi experiment yang merupakan pengembangan dari true expertimental design (Sugiyono, 2013).

Pada penelitian ini penulis membagi sampel menjadi dua kelompok yaitu kelompok eksperimen dan kelompok kontrol. Kelompok eksperimen adalah kelompok yang diberi perlakuan dalam pembelajarannya dengan menggunakan model pembelajaran problem posing sedangkan kelompok kontrol mendapat perlakuan dalam pembelajarannya dengan menggunakan model pembelajaran konvensional. Model Pembelajaran Konvensional adalah pendekatan yang biasa digunakan di sekolah dalam proses pembelajaran, dalam hal ini pembelajaran yang biasa dilakukan adalah ekspositori.

Populasi dalam penelitian ini adalah seluruh siswa MTs Ar Raswad Cengal Tahun 2015/2016 kelas VII sebanyak 3 kelas yang berjumlah 102 siswa. Teknik pengambilan sampel pada penelitian ini menggunakan sampling purvosive yaitu teknik penentuan sampel yang dilakukan dengan pertimbangan tertentu (Sugiyono, 2013). Pertimbangan yang diperoleh dalam penelitian ini adalah pertimbangan dari pihak guru mata pelajaran matematika pada sekolah yang hendak dijadikan tempat penelitian. Dalam penelitian ini dari 3 kelas diambil menjadi dua kelas, yaitu kelas VII.B sebagai kelas eksperimen, dan kelas VII.C sebagai kelas kontrol dengan pertimbangan kemampuan belajar yang dimiliki siswa tersebut tidak jauh berbeda menurut rekomendasi guru matematika kelas VII MTs Ar Raswad Cengal. Instrumen yang digunakan untuk mengukur kemampuan penalaran matematis digunakan tes kemampuan penalaran matematis yang diberikan dalam bentuk tes uraian (essay).

Data KAM yang merupakan hasil ulangan harian pada pokok bahasan sebelumnya digunakan untuk mengelompokan kategori KAM siswa (tinggi, sedang, dan rendah) dengan aturan sebagai berikut. 
Tabel 1 Kriteria Pengelompokan KAM

\begin{tabular}{cc}
\hline Kriteria & Kategori \\
\hline $\mathrm{KAM} \geq \overline{\boldsymbol{x}}+\boldsymbol{s}$ & Tinggi \\
$\overline{\boldsymbol{x}}-\boldsymbol{s}<\mathrm{KAM}<\overline{\boldsymbol{x}}+\boldsymbol{s}$ & Sedang \\
$\overline{\boldsymbol{x}}-\boldsymbol{s} \leq \mathrm{KAM}$ & Rendah \\
\hline
\end{tabular}

Keterangan:

$\bar{x}$ : rata-rata kelas

$s$ : simpangan baku

Teknik analisis data yang digunakan meliputi Uji Normalitas, Uji Homogenitas, Uji t, Uji t', Uji Mann Whitney, serta Uji Anova Satu Jalur dan Uji Kruskal Wallis. Analisis data yang dilakukan, menggunakan bantuan software SPSS 19.0 for Windows dan Microsoft Office Excel 2010. Selanjutnya kriteria pengujian hipotesis mengikuti aturan jika nilai Sig. $(\mathrm{p}$-value $) \geq$ taraf signifikansi $(\alpha=0,05)$ maka $\mathrm{H}_{0}$ diterima, sebaliknya jika nilai Sig. $(\mathrm{p}$-value $)<$ taraf signifikansi $(\alpha=0,05)$ maka $\mathrm{H}_{0}$ ditolak.

\section{HASIL DAN PEMBAHASAN}

Kelompok eksperimen adalah kelompok yang memperoleh pembelajaran matematika melalui model pembelajaran problem posing sedangkan kelompok kontrol adalah kelompok yang memperoleh pembelajaran matematika secara konvensional yakni ekspositori. Ada beberapa data pada penelitian ini yakni data KAM yang terdiri dari KAM kelas eksperimen dan KAM kelas kontrol, data N-Gain yang merupakan data peningkatan kemampuan penalaran matematis siswa baik itu kelas eksperimen maupun kelas kontrol yang selanjutnya dikelompokan berdasarkan kategori KAM siswa (tinggi, sedang, dan rendah). Berikut ini disajikan data hasil penelitian:

Tabel 2 Deskripsi Data Hasil Penelitian

\begin{tabular}{llllllll}
\hline \multirow{2}{*}{ Kategori } & \multirow{2}{*}{ Skor } & \multicolumn{3}{c}{ Eksperimen } & \multicolumn{3}{c}{ Kontrol } \\
\cline { 3 - 8 } & & N & $\overline{\boldsymbol{x}}$ & $\boldsymbol{s}$ & $\mathbf{N}$ & $\overline{\boldsymbol{x}}$ & $\boldsymbol{s}$ \\
\hline Keseluruhan & KAM & 33 & 48,23 & 16,90 & 33 & 44,56 & 13,46 \\
Keseluruhan & N-Gain & 33 & 0,48 & 0,18 & 33 & 0,18 & 0,12 \\
KAM Tinggi & N-Gain & 7 & 0,56 & 0,19 & 5 & 0,11 & 0,08 \\
KAM Sedang & N-Gain & 20 & 0,45 & 0,19 & 23 & 0,21 & 0,12 \\
KAM Rendah & N-Gain & 6 & 0,49 & 0,16 & 5 & 0,13 & 0,06 \\
\hline
\end{tabular}


Dari tabel tersebut tampak bahwa pada kelas eksperimen terdapat 33 siswa dengan nilai rata-rata KAM 48,23 serta standar deviasi KAM 16,90 dan rata-rata N-Gain 0,48 serta standar deviasi N-Gain 0,18. Sedangkan kelas kontrol terdapat 33 siswa dengan nilai ratarata KAM 44,56 serta standar deviasi KAM 13,46 dan rata-rata N-Gain 0,18 serta standar deviasi N-Gain 0,12.

Pada tabel tersebut juga terlihat kelas eksperimen terbagi kedalam kelompok KAM tinggi sebanyak 7 siswa dengan rata-rata $\mathrm{N}$-Gain 0,56 dan standar deviasi N-Gain 0,19; kelompok KAM sedang sebanyak 20 siswa dengan rata-rata N-Gain 0,45 dan standar deviasi N-Gain 0,19; dan kelompok KAM rendah sebanyak 6 siswa dengan rata-rata $\mathrm{N}$ Gain 0,49 dan standar deviasi N-Gain 0,16. Sedangkan pada kelas kontrol terbagi kedalam KAM tinggi sebanyak 5 siswa dengan rata-rata $\mathrm{N}$-Gain 0,11 dan standar deviasi N-Gain 0,08; kelompok KAM sedang sebanyak 23 siswa dengan rata-rata N-Gain 0,21 dan standar deviasi N-Gain 0,12; dan kelompok KAM rendah sebanyak 5 siswa dengan rata-rata $\mathrm{N}$ Gain 0,13 dan standar deviasi N-Gain 0,06.

Tabel tersebut menunjukkan bahwa secara keseluruhan rata-rata $\mathrm{N}$-gain kelas eksperimen lebih tinggi daripada rata-rata N-gain kelas kontrol. Artinya secara deskriptif dapat disimpulkan bahwa peningkatan penalaran matematis siswa yang memperoleh pembelajaran matematika melalui model pembelajaran problem posing lebih baik daripada peningkatan penalaran matematis siswa yang memperoleh pembelajaran matematika secara konvensional.

Selanjutnya pada kategori KAM tinggi, sedang, dan rendah pun rata-rata N-gain kelas eksperimen lebih tinggi daripada rata-rata N-gain kelas kontrol. Artinya secara deskriptif pada kategori KAM tinggi, sedang, dan rendah, peningkatan kemampuan penalaran matematis siswa yang memperoleh pembelajaran matematika melalui model pembelajaran problem posing lebih baik daripada peningkatan kemampuan penalaran matematis siswa yang memperoleh pembelajaran matematika secara konvensional.

Selanjutnya untuk menelaah lebih lanjut data tersebut dilakukan berbagai analisis data. Analisis data KAM dilakukan untuk melihat ada tidaknya perbedaan yang signifikan antara KAM kelas eksperimen dengan KAM kelas kontrol. Analisis data yang dilakukan meliputi uji normalitas, uji homogenitas, dan uji kesamaan dua rerata. Analisis data NGain dilakukan berdasarkan kelas dan berdasarkan kategori KAM untuk melihat ada tidaknya perbedaan secara signifikan dan mana N-Gain yang lebih baik dari kelompokkelompok yang dibandingkan. Analisis data yang dilakukan meliputi Uji Normalitas, Uji Homogenitas, dan uji perbandingan rerata yang meliputi Uji t, Uji t', Uji Mann Whitney, 
serta Uji Anova Satu Jalur dan Uji Kruskal Wallis. Berikut ini disajikan hasil uji statistik data hasil penelitian:

\section{Tabel 3 Uji Statistik Data Hasil Penelitian}

\begin{tabular}{llcc}
\hline Kategori & Kelas yang Dijuji & $\begin{array}{c}\text { Data yang Diuji } \\
\text { (Skor) }\end{array}$ & $\begin{array}{c}\text { Hasil Uji Statistik } \\
\text { (Nilai Sig.) }\end{array}$ \\
\hline Keseluruhan & $\begin{array}{l}\text { Kelas Eksperimen } \\
\text { dengan Kontrol }\end{array}$ & KAM & 0,477 \\
Keseluruhan & $\begin{array}{l}\text { Kelas Eksperimen } \\
\text { dengan Kontrol }\end{array}$ & N-Gain & 0,000 \\
KAM kelas & Kelas Eksperimen & N-Gain & 0,428 \\
$\begin{array}{l}\text { Problem posing } \\
\text { KAM kelas }\end{array}$ & Kelas Kontrol & N-Gain & 0,107 \\
Konvensional & Kelas Eksperimen & N-Gain & 0,000 \\
KAM Tinggi & $\begin{array}{l}\text { dengan Kontrol } \\
\text { Kelas Eksperimen }\end{array}$ & N-Gain & 0,000 \\
KAM Sedang & $\begin{array}{l}\text { Kengan Kontrol } \\
\text { Kelas Eksperimen } \\
\text { dengan Kontrol }\end{array}$ & N-Gain & 0,001 \\
\hline
\end{tabular}

Analisis data KAM dilakukan untuk melihat ada tidaknya perbedaan yang signifikan antara KAM kelas eksperimen dengan KAM kelas kontrol. Hipotesis $\mathrm{H}_{0}$ berbunyi "Tidak terdapat perbedaan rata-rata KAM siswa diantara kedua kelas" sedangkan $\mathrm{H}_{1}$ berbunyi "Terdapat perbedaan rata-rata KAM siswa diantara kedua kelas". Setelah dilakukan uji normalitas selanjutnya dilakukan uji Mann Whitney karena data tidak berdistribusi normal. Pada tabel tersebut terlihat bahwa nilai sig adalah $>0,05(0,477)$. Dengan demikian $\mathrm{H}_{0}$ diterima, artinya dari data tersebut dapat disimpulkan bahwa tidak terdapat perbedaan kemampuan awal matematis (KAM) siswa antara kelas eksperimen dan kelas kontrol secara siginfikan.

Analisis data N-Gain dengan kategori keseluruhan dilakukan untuk membandingkan mana yang lebih baik secara signifikan antara rata-rata $\mathrm{N}$-Gain kelas eksperimen dengan rata-rata $\mathrm{N}$-Gain kelas kontrol. Hipotesis $\mathrm{H}_{0}$ berbunyi "Rata-rata $\mathrm{N}$ Gain siswa kelas eksperimen kurang dari atau sama dengan rata-rata N-Gain siswa kelas kontrol" sedangkan $\mathrm{H}_{1}$ berbunyi "Rata-rata $\mathrm{N}$-Gain siswa kelas eksperimen lebih tinggi 
dari rata-rata N-Gain siswa kelas kontrol". Setelah dilakukan uji normalitas selanjutnya dilakukan uji Mann Whitney karena data tidak berdistribusi normal.

Pada tabel tersebut terlihat bahwa nilai sig adalah $<0,05(0,000)$. Dengan demikian $\mathrm{H}_{0}$ ditolak, artinya dari data tersebut dapat disimpulkan bahwa rata-rata N-Gain siswa kelas eksperimen lebih tinggi dari rata-rata N-Gain siswa kelas kontrol secara signifikan. Dari hasil analisis tersebut dapat disimpulkan secara statistik bahwa peningkatan kemampuan penalaran matematis siswa yang memperoleh pembelajaran matematika melalui model pembelajaran problem posing lebih baik daripada peningkatan kemampuan penalaran matematis siswa yang memperoleh pembelajaran matematika secara konvensional.

Analisis data N-Gain dengan kategori KAM kelas problem posing dilakukan untuk melihat perbedaan secara signifikan rata-rata $\mathrm{N}$-Gain kelas eksperimen ditinjau berdasarkan KAM tinggi, KAM sedang, dan KAM rendah. Hipotesis $\mathrm{H}_{0}$ berbunyi "Tidak terdapat perbedaan rata-rata N-Gain kelas eksperimen antara siswa kelompok KAM tinggi, sedang, dan rendah" sedangkan $\mathrm{H}_{1}$ berbunyi "Terdapat perbedaan rata-rata N-Gain kelas eksperimen antara siswa kelompok KAM tinggi, sedang, dan rendah”. Setelah dilakukan uji normalitas dan uji homogenitas selanjutnya dilakukan uji Anova karena data berdistribusi normal dan homogen.

Pada tabel tersebut terlihat bahwa nilai sig adalah > 0,05 (0,428). Dengan demikian $\mathrm{H}_{0}$ diterima, artinya dari data tersebut dapat disimpulkan bahwa tidak terdapat perbedaan rata-rata $\mathrm{N}$-Gain kelas eksperimen antara siswa kelompok KAM tinggi, sedang, dan rendah secara signifikan. Dari hasil analisis tersebut dapat disimpulkan secara statistik bahwa tidak terdapat perbedaan peningkatan kemampuan penalaran matematis siswa yang memperoleh pembelajaran matematika melalui model pembelajaran problem posing apabila ditinjau berdasarkan KAM tinggi, sedang, dan rendah.

Analisis data N-Gain dengan kategori KAM kelas Konvensional dilakukan untuk melihat perbedaan secara signifikan rata-rata N-Gain kelas kontrol ditinjau berdasarkan KAM tinggi, KAM sedang, dan KAM rendah. Hipotesis $\mathrm{H}_{0}$ berbunyi “Tidak terdapat perbedaan rata-rata N-Gain kelas kontrol antara siswa kelompok KAM tinggi, sedang, dan rendah" sedangkan $\mathrm{H}_{1}$ berbunyi "Terdapat perbedaan rata-rata $\mathrm{N}-$ Gain kelas kontrol antara siswa kelompok KAM tinggi, sedang, dan rendah". Setelah dilakukan uji normalitas dan uji homogenitas selanjutnya dilakukan uji Kruskal Wallis karena data berdistribusi normal tetapi tidak homogen.

Pada tabel tersebut terlihat bahwa nilai sig adalah > 0,05 (0,107). Dengan demikian $\mathrm{H}_{0}$ diterima, artinya dari data tersebut dapat disimpulkan bahwa tidak terdapat perbedaan 
rata-rata N-Gain kelas kontrol antara siswa kelompok KAM tinggi, sedang, dan rendah secara signifikan. Dari hasil analisis tersebut dapat disimpulkan secara statistik bahwa tidak terdapat perbedaan peningkatan kemampuan penalaran matematis siswa yang memperoleh pembelajaran matematika secara konvensional apabila ditinjau berdasarkan KAM tinggi, sedang, dan rendah.

Analisis data N-Gain dengan kategori KAM Tinggi dilakukan untuk membandingkan mana yang lebih baik secara signifikan antara rata-rata $\mathrm{N}$-Gain kelompok KAM Tinggi kelas eksperimen dengan rata-rata N-Gain kelompok KAM Tinggi kelas kontrol. Hipotesis $\mathrm{H}_{0}$ berbunyi "Rata-rata $\mathrm{N}$-Gain kelompok KAM Tinggi siswa kelas eksperimen kurang dari atau sama dengan rata-rata N-Gain kelompok KAM Tinggi siswa kelas kontrol" sedangkan $\mathrm{H}_{1}$ berbunyi "Rata-rata N-Gain kelompok KAM Tinggi siswa kelas eksperimen lebih tinggi dari rata-rata N-Gain kelompok KAM Tinggi siswa kelas kontrol". Setelah dilakukan uji normalitas dan uji homogenitas selanjutnya dilakukan uji t karena data berdistribusi normal dan homogen.

Pada tabel tersebut terlihat bahwa nilai sig adalah $<0,05(0,000)$. Dengan demikian $\mathrm{H}_{0}$ ditolak, artinya dari data tersebut dapat disimpulkan bahwa rata-rata N-Gain kelompok KAM Tinggi siswa kelas eksperimen lebih tinggi dari rata-rata N-Gain kelompok KAM Tinggi siswa kelas kontrol secara signifikan. Dari hasil analisis tersebut dapat disimpulkan secara statistik bahwa peningkatan kemampuan penalaran matematis siswa kelompok KAM tinggi yang memperoleh pembelajaran matematika melalui model pembelajaran problem posing lebih baik daripada peningkatan kemampuan penalaran matematis siswa kelompok KAM tinggi yang memperoleh pembelajaran matematika secara konvensional.

Analisis data N-Gain dengan kategori KAM Sedang dilakukan untuk membandingkan mana yang lebih baik secara signifikan antara rata-rata $\mathrm{N}$-Gain kelompok KAM Sedang kelas eksperimen dengan rata-rata N-Gain kelompok KAM Sedang kelas kontrol. Hipotesis $\mathrm{H}_{0}$ berbunyi "Rata-rata $\mathrm{N}$-Gain kelompok KAM Sedang siswa kelas eksperimen kurang dari atau sama dengan rata-rata N-Gain kelompok KAM Sedang siswa kelas kontrol" sedangkan $\mathrm{H}_{1}$ berbunyi "Rata-rata N-Gain kelompok KAM Sedang siswa kelas eksperimen lebih tinggi dari rata-rata N-Gain kelompok KAM Sedang siswa kelas kontrol'. Setelah dilakukan uji normalitas dan uji homogenitas selanjutnya dilakukan uji t' karena data berdistribusi normal tetapi tidak homogen.

Pada tabel tersebut terlihat bahwa nilai sig adalah $<0,05(0,000)$. Dengan demikian $\mathrm{H}_{0}$ ditolak, artinya dari data tersebut dapat disimpulkan bahwa rata-rata N-Gain kelompok KAM Sedang siswa kelas eksperimen lebih tinggi dari rata-rata N-Gain kelompok KAM 
Sedang siswa kelas kontrol secara signifikan. Dari hasil analisis tersebut dapat disimpulkan secara statistik bahwa peningkatan kemampuan penalaran matematis siswa kelompok KAM sedang yang memperoleh pembelajaran matematika melalui model pembelajaran problem posing lebih baik daripada peningkatan kemampuan penalaran matematis siswa kelompok KAM sedang yang memperoleh pembelajaran matematika secara konvensional.

Analisis data N-Gain dengan kategori KAM Rendah dilakukan untuk membandingkan mana yang lebih baik secara signifikan antara rata-rata N-Gain kelompok KAM Rendah kelas eksperimen dengan rata-rata N-Gain kelompok KAM Rendah kelas kontrol. Hipotesis $\mathrm{H}_{0}$ berbunyi "Rata-rata N-Gain kelompok KAM Rendah siswa kelas eksperimen kurang dari atau sama dengan rata-rata N-Gain kelompok KAM Rendah siswa kelas kontrol" sedangkan $\mathrm{H}_{1}$ berbunyi "Rata-rata $\mathrm{N}$-Gain kelompok KAM Rendah siswa kelas eksperimen lebih tinggi dari rata-rata N-Gain kelompok KAM Rendah siswa kelas kontrol". Setelah dilakukan uji normalitas dan uji homogenitas selanjutnya dilakukan uji t' karena data berdistribusi normal tetapi tidak homogen.

Pada tabel tersebut terlihat bahwa nilai sig adalah $<0,05(0,001)$. Dengan demikian $\mathrm{H}_{0}$ ditolak, artinya dari data tersebut dapat disimpulkan bahwa secara signifikan rata-rata N-Gain kelompok KAM Rendah siswa kelas eksperimen lebih tinggi dari rata-rata N-Gain kelompok KAM Rendah siswa kelas control secara signifikan. Dari hasil analisis tersebut dapat disimpulkan secara statistik bahwa peningkatan kemampuan penalaran matematis siswa kelompok KAM rendah yang memperoleh pembelajaran matematika melalui model pembelajaran problem posing lebih baik daripada peningkatan kemampuan penalaran matematis siswa kelompok KAM rendah yang memperoleh pembelajaran matematika secara konvensional.

Problem posing merupakan suatu pembelajaran di mana siswa diminta untuk mengajukan masalah (problem) berdasarkan situasi tertentu (Lestari \& Yudhanegara, 2015). Pengajuan soal merupakan tugas yang mengarah pada sikap kritis dan kreatif sebab siswa diminta untuk membuat pertanyaan dari informasi yang diberikan (Shohimin, 2014).

Dalam model pembelajaran problem possing siswa tidak hanya diminta untuk membuat soal atau mengajukan pertanyaan, tetapi mencari penyelesainya. Pada dasarnya setiap penyelesaian soal matematika memerlukan kemampuan penalaran, sehingga kemampuan penalaran matematis siswa menjadi terasah selama proses pembelajaran menggunakan model pembelajaran problem posing. Lebih lanjut Shohimin (2014) mengatakan apabila dikaitkan dengan peningkatan kemampuan siswa, pengajuan soal merupakan sarana untuk merangsang kemampuan tersebut. Sehingga tidak lah 
mengherankan apabila peningkatan kemampuan penalaran matematis siswa yang memperoleh pembelajaran matematika melalui model pembelajaran problem posing lebih baik daripada peningkatan kemampuan penalaran matematis siswa yang memperoleh pembelajaran matematika secara konvensional baik ditinjau secara keseluruhan kelas maupun berdasarkan KAM tinggi, sedang, dan rendah. Hal tersebut juga sejalan dengan kelebihan model pembelajaran problem posing yaitu mendidik murid untuk berpikir kritis dan belajar menganalisis suatu masalah (Shohimin, 2014).

\section{KESIMPULAN}

Berdasarkan analisis yang dilakukan, diperoleh kesimpulan bahwa apabila ditinjau secara keseluruhan, peningkatan kemampuan penalaran matematis siswa yang memperoleh pembelajaran matematika melalui model pembelajaran problem posing lebih baik daripada peningkatan kemampuan penalaran matematis siswa yang memperoleh pembelajaran matematika secara konvensional. Selanjutnya apabila ditinjau berdasarkan KAM tinggi, sedang, dan rendah, tidak terdapat perbedaan peningkatan kemampuan pemecahan masalah matematis baik itu pada siswa yang memperoleh pembelajaran matematika melalui model pembelajaran problem posing maupun pada siswa yang memperoleh pembelajaran matematika secara konvensional. Akan tetapi pada kategori KAM tinggi, sedang, dan rendah peningkatan kemampuan penalaran matematis siswa yang memperoleh pembelajaran matematika melalui model pembelajaran problem posing lebih baik daripada peningkatan kemampuan penalaran matematis siswa yang memperoleh pembelajaran matematika secara konvensional.

Adapun saran untuk penerapan pembelajaran matematika melalui model pembelajaran problem posing, sebaiknya dilakukan penelitian lebih lanjut di tahun-tahun mendatang mengenai pembelajaran matematika melalui model pembelajaran problem posing untuk kemampuan matematika lainnya seperti komunikasi matematis, koneksi matematis, dan kemampuan-kemampuan matematis lainnya sehingga diperoleh suatu kesimpulan yang menyeluruh.

\section{DAFTAR PUSTAKA}

Lestari, K. E., \& Yudhanegara, M. R. 2015. Penelitian Pendidikan Matematika. Bandung: Refika Aditama.

Shadiq, F. 2014. Pembelajaran Matematika. Yogyakarta: Graha Ilmu.

Shohimin, A. 2014. 68 Model Pembelajaran Inovatif dalam Kurikulum 2013. Yogyakarta: Ar-Ruzz Media. 
22 Analisis Peningkatan Kemampuan Penalaran Matematis Melalui Penerapan Model Pembelajaran Problem Posing Ditinjau Berdasarkan Kemampuan Awal Matematis Siswa

Sugiyono. 2013. Metode Penelitian Pendidikan Pendekatan Kualitatif, Kuantitatif dan $R \& D$. Bandung: Alfabeta.

Sumarmo, U. 2013. Berpikir dan Disposis Matematika serta Pembelajaranna. Bandung: FPMIPA UPI. 